\title{
Factors Motivating and Inhibiting the Practice of HRIS in Business Organizations: An Empirical Analysis
}

\author{
Rand H. Al-Dmour ${ }^{1} \&$ Zu'bi M. F. Al-Zu'bi ${ }^{2}$ \\ ${ }^{1}$ Brunel Business School, Brunel University, London, UK \\ ${ }^{2}$ School of Business, The University of Jordan, Amman, Jordan \\ Correspondence: Zu'bi M. F. Al-Zu’bi, School of Business, the University of Jordan, P. O. Box 13413, Amman, \\ 11942 Jordan. Tel: 962-79-562-939. E-mail: z.alzubi@ju.edu.jo
}

Received: April 3, 2014

Accepted: May 7, 2014

Online Published: June 25, 2014

doi:10.5539/ibr.v7n7p139

URL: http://dx.doi.org/10.5539/ibr.v7n7p139

\begin{abstract}
Human Resource Information System (HRIS) software helps the HR function to comply with the human resource (HR) requirements of an organization using web-technology-based channels. The main purposes of this study are to examine the extent to which business organizations in Jordan, as a developing country, have adopted HRIS and to examine the current HRIS usage, benefits, and barriers exhibited within these organizations. A questionnaire was written based on an analysis of previous work. Results indicate that the most frequent applications of HRIS used in business organizations in Jordan are "Employee Records," followed by "Pay Roll" and "Recruitment/Selection." Use of sophisticated HRIS applications, such as "Succession Planning," "Performance Appraisal," "Compensation Management," and "Training and Development" were also found in organizations throughout Jordan. The results showed that the benefits of HRIS include quicker response time, more accurate HR information, reduction of paperwork and manpower, and more efficient tracking and controlling, while the greatest barriers were perceived to be cost implications and inadequate knowledge in implementing the system.
\end{abstract}

Keywords: electronic human resources management, e-HRM, Human Resource Information System (HRIS), HRIS implementation

\section{Introduction}

The HR function of an organization is in charge of meeting all of the organization's HR requirements. As with other managerial functions, HR strategies, policies, and practices are implemented to ensure smooth operation of the organization in a sustainable manner. Using HRIS (Human Resource Information System) technology is a way of putting into practice these HR strategies, policies, and practices by complying with the HR requirements of an organization more efficiently, through web-technology-based channels (Ruël et al., 2004). HRIS is an integrated system comprised of the databases, computer applications, hardware, and software necessary to collect, record, store, manage, deliver, present, and manipulate data for a company's human resources function (Broderick \& Boudreau, 1992).

The last two decades have seen the publication of many studies on the adoption and use of HRIS, including on the type of applications that dominate HRIS (Clark et al., 2000), the necessary antecedents for successful implementation of HRIS (e.g., Yeh, 1997), the factors that encourage successful HRIS implementation (Haines \& Petit, 1997), and general organizational adoption (e.g., Panayotopoulou et al., 2007; Lau \& Hooper, 2008). Most of these studies were tested in economically developed countries, such as the UK and other European countries (Panayiotopoulos et al., 2007), while studies in developing countries are very limited in number. HRIS in Jordan should be considered as a new IT tool in business originations.

This study identifies the main factors motivating and inhibiting the use of HRIS applications in shareholding companies in Jordan. Moreover, it provides relevant decision-makers with recommendations that may help HR departments to improve their use of HRIS applications. The rationale behind this is to gain a better understanding of the current status, benefits, and impediments to the use of HRIS in developing countries. To the best knowledge of the authors, this study is one of the only that has attempted to understand the implementation of HRIS in the Jordanian environment. Furthermore, as will be shown in the literature review, the current body of 
research on HRIS implementation largely focuses on the developed world. This study will expand the scope of the literature by examining Jordan, a developing country.

\subsection{Research Problem}

This study originated to address the gaps in knowledge left by previous research, by identifying the main factors motivating and/or inhibiting the practice of HRIS in business organizations in Jordan, as a developing country.

The study problem primarily attempts to answer the following questions:

1) To what extent are HRIS applications being utilized in business organizations?

2) What do HR managers see as the benefits of HRIS applications?

3) What are the main barriers to implementation of HRIS in business organizations?

\subsection{Research Objectives}

The key objectives of this study are as follows:

1) To identify the extent to which HRIS functions are used by Jordanian business organizations.

2) To identify the strength and direction of the relationship between the perceived benefits of HRIS and the extent of its applications being practiced in business organizations.

3) To identify the strength and direction of the relationship between the perceived barriers of HRIS and the extent of its applications being practiced in business organizations.

4) To discover the extent to which a business' demographic characteristics (e.g. type of business, organization size, and level of business experience) affect the relationship between the perceived benefits and barriers of adopting HRIS and the extent of its applications being practiced in business organizations.

5) To provide relevant decision makers with the recommendations needed to improve their companies' use of HRIS applications.

\subsection{Research Importance}

This study's importance stems from the following points:

1) To the best knowledge of the researchers, this study is one of the few attempts to research the relationship between the perceived benefit and barriers of HRIS and the extent of HRIS usage in business organizations in Jordan.

2) As seen in the literature, previous studies on the practice of HRIS have been focused on developed countries. This research will expand its view to look at developing countries, namely Jordan.

3) An enhanced understanding of the factors that influence HRIS implementation levels may be helpful to both mangers and practitioners.

\section{Literature Review}

In order to find empirical studies focusing on HRIS, the authors used a scholarly Internet search engine (scholar.google.com) in concert with several online databases covering a number of leading international journals. These journals covered the fields of human resources and general management as well as e-business, the quickly growing field of HRIS, and industrial and organizational behavior. For the purpose of this study, the previous studies have been grouped under the following headings:

\subsection{HRIS Definitions and Role}

Several definitions of HRIS can be found in previous studies. One of the earliest definitions comes from DeSanctis (1986), describing it along the lines of a systematic procedure for the functions of collection, storing, maintaining, retrieving, and validating data for the use of the human resource and organization unit characteristics. Tannenbaum (1990) defines HRIS as "a technology-based system used to acquire, store, manipulate, analyze, retrieve, and distribute pertinent information regarding an organization's human resources." Kovach et al. (1999) define HRIS as a systematic procedure for "collecting, storing, maintaining, retrieving, and validating data needed by an organization about its human resources," personnel activities, and organizational unit characteristics.

According to the above definitions, the value of an HRIS can be measured as the resulting improvement to the administrative HR processes, not transformational outcomes of electronic human resource management (e-HRM), such as employee involvement or work force alignment, which can be ignored. Lengnick-Hall and Moritz (2003) have proposed that HRIS will be utilized at three different levels: the publishing of information; 
the automation of transactions; and, finally, a transformation in the way human resource management (HRM) is conducted in companies, by making HR a strategic partner. Thus, the changes in HR, as encouraged by HRIS, evolve from information to automation, then from automation to transformation. This evolution is proposed by Lengnick-Hall, Moritz, and Walker (2001) as allowing HIRS to create informational efficiencies and cost saving, in turn enabling HR departments to better focus their attention on analyzing current data, which can be used for strategic decision making. Similarly, Haines and Petit (1997) noted that cost savings from routine tasks will develop more interactive participation in the strategic decision making and this has been reinforced in Kavanagh, et al. (1990) which concluded that HRIS functions interact with most HRM systems-primarily planning, staffing, training and career development, performance management, and compensation management. They also described HRIS as a three-level continuum, consisting of electronic data processing (EDP), a management information system (MIS), and a decision support system (DSS).

The many applications of HRIS, in combination with the decreasing cost of computer systems (especially microcomputer systems) and the increasing ease of use of computer applications, have resulted in HRIS being viewed as an increasingly attractive option by practitioners. In addition to storing data, HRIS also allows certain tasks to be completed more easily and reduces the amount of paper that HR departments must store. HRIS has many possible uses, including: clerical applications, applicant search expenditures, risk management, training management, training experience, financial planning, turnover analysis, succession planning, flexible-benefits administration, compliance with government regulations, attendance reporting and analysis, human resource planning, accident reporting, and prevention and strategic planning (Byars \& Rue, 2004). A summary of HRIS applications is given in Table 1 (below).

Table 1. A summary of HRIS applications

\begin{tabular}{|c|c|}
\hline HRIS Applications & References \\
\hline 1. Recruitment and Selection & $\begin{array}{l}\text { Galanaki, 2002; Mooney, 2002; Ngai, et al., 2008; Verhoeven \& } \\
\text { Williams, 2008; Junaid, et al., } 2010\end{array}$ \\
\hline 2. Training and Development & Karakanian, 2000; Teo, et al., 2001; Hendrickson, 2003 \\
\hline $\begin{array}{l}\text { 3. Payroll, Benefits, and Compensation } \\
\text { Management/Administration }\end{array}$ & Andrew \& Satish, 2001; Ngai, et al., 2008; Workforce Solutions, 2009 \\
\hline 4. Performance Appraisal & Adamson \& Zampetti, 2001; Hansen \& Deimler, 2001 \\
\hline 5. Human Resource Planning & Walker, 1993; Ngai, et al., 2008 \\
\hline 6. Internal and External Communication & Karakanian, 2000; Ngai, et al., 2008 \\
\hline 7. Self-Service (including Web Portals) & O' Connell, 1996; Roberts, 1999; Ngai, et al., 2008 \\
\hline
\end{tabular}

\subsection{Perceived Benefits of HRIS}

Perceived benefits have a central role in the adoption of new innovations (Lacovou, et al., 1995; Rogers, 1995). Snell, Stueber, and Lepak (2002) report that information technology (IT), which "allows firms to store and retrieve large amounts of information quickly and inexpensively," can help HR become more strategic, flexible, cost-efficient, and customer oriented. They argue that adopting HRIS can help to simultaneously lower administrative costs, increase productivity, diminish response time, improve decision-making, and enhance customer service. In a 1992 survey, Overman stated that the possible benefits of HRIS include faster information processing, greater information accuracy, improved planning and program development, and enhanced employee communications.

In a 2002 survey, Watson and Wyatt discovered that the top four metrics used in formal business cases supporting HRIS were increased productivity within HR organization, a decrease in costs, return on investment, and improved employee communications. Broderick and Boudreau (1992) similarly found that HRIS decreases costs, improves customer satisfaction, and increases innovation. Boateng (2007) notes that aside from cost reductions and productivity improvements, HRIS potentially and fundamentally affects revenue channels. According to the work of Sadri and Chatterjee (2003), computerized HRIS functions allow for faster decision making, development, planning, and administration of HR because data is much easier to store, update, classify, and analyze. Additionally, they noted that HRIS could build a company's character.

Kettley and Reilly (2003) report that the potential benefits of HRIS can be divided into three areas: "1) 
Operational Efficiency-reducing overhead costs, enhancing the accuracy of data, eliminating the costs of printing and disseminating information, minimizing IT infrastructure costs by moving towards a common HR service platform, and enhancing the ability to distribute HR information and services globally; 2) Relational Impact-changing the nature of the relationship between HR, line managers, and employees; and 3) Transformational Impact-transforming HR's role into that of a strategic business partner, adding greater value to the business by increasing HR's influence as customer-focused consultants, expanding HR's reach to different employee groups, and enabling new, flexible response methods for delivering HR services."

Bhavsar (2011) argues that a properly-developed HRIS offers the following benefits: 1) Decrease in the cost of stored data in human resource; 2) Quicker speed of retrieval and processing of data; 3) Reduction in duplication of efforts, leading to decrease in cost; 4) Availability of accurate and timely data about human resources; 5) Better analysis leading to more effective decision-making; 6) More meaningful career planning and counseling at all levels; 7) Improved quality of reports; 8) Better ability to respond to environmental changes; and 9) More transparency in the system.

Beckers and Bsat (2002) list five primary benefits that companies can receive from HRIS: (1) Increase competitiveness by improving HR operations; (2) Produce a greater number and variety of HR-related reports; (3) Change the focus of HR from the processing of transactions to strategic HRM; (4) Involve employees in HRIS; and (5) Reengineer the entire HR function of companies. These reasons are echoed by several other researchers (Lederer, 1984; Kovach et al., 2002).

Bhaskar (2011) states, "In the current fast-paced global competitive business environment, the efficient and effective management of human capital is an immense challenge to the human resource departments. Information systems contribute to improve the organizational performance, and enhance the competencies of human resource professionals." Edward (cited in Softworld Report, 1996) instead focuses on the more tangible benefits of HRIS such as faster response times of HR managers to organizational management with certain organizations taking a more long-term view, saying, "HR managers can improve both their company's performance and their own status within the company, by honing their knowledge of the packages on the market and what they are capable of delivering." (p23)

Russell and Michael (1988) and Thomas and Anne (1997) concluded that the integration of information systems within an HR department could lead organizations to acquire increased HRM competency. Moreover, researchers addressed the relationship between HRM practices and competitive advantage, observing that HRM can lead to a competitive advantage by strengthening the set of role behavior that results in reduced cost and product differentiation (Augustine \& Mary, 1994; Carol, 1998; Zahid, et al., 2007).

A 2004 study carried out by Ngai et al. addresses the perceived advantages of implementing HRIS. The researchers found that most Hong Kong industries perceived quick response time and increased access to information to be the greatest benefits in implementing HRIS, while the greatest impediment was insufficient funding. These findings are supported by those of Kovach and Cathcart (1999), Beckers and Bsat (2002), and the Institute of Management and Administration (2002), who found that a comprehensive HRIS necessitates a large budget to implement and maintain. Ngai et al. (2004) also found a statistically significant difference regarding certain potential advantages and barriers to implementation of HRIS between HRIS adopters and non-adopters, as well as between small, medium, and large organizations.

Table 2. A summary of perceived benefits of the adoption of HRIS

\begin{tabular}{|c|c|}
\hline Benefits of HRIS & Discussed by \\
\hline $\begin{array}{l}\text { 1) Cost reduction: } \\
\text { - Wide spread access to HR information on a virtual basis decreases HR transaction costs; } \\
\text { leveraging law of digital assets to use the information } \\
\text { - Substitutes physical capability by leveraging law of digital assets to use the information. }\end{array}$ & $\begin{array}{l}\text { Broderick \& Boudreau, 1992; Ensher, } \\
\text { et al., 2002; Alleyne, 2003; } \\
\text { Panayotopoulou, et al., 2007; Martin, } \\
\text { et al., } 2009\end{array}$ \\
\hline $\begin{array}{l}\text { 2) Improving HR services: } \\
\text { - Increases flexibility in work, promotes innovation, and individualizes labor relations; } \\
\text { - Improves quality and consistency of HR information; } \\
\text { - Decreases the amount of time spent on employees' repetitive questions; } \\
\text { - Improves perception of management and employees of the HR function. }\end{array}$ & $\begin{array}{l}\text { Wright \& Dyer, 2000; Zampetti \& } \\
\text { Adamson, 2001; Martin, et al., 2009; } \\
\text { Mohapatra, 2009; Junaid, et al., 2010; } \\
\text { Wachira, 2010; Krishna \& Bhaskar, } \\
2011\end{array}$ \\
\hline
\end{tabular}


3) Redefining employee responsibilities in HR:

- Makes it easier for managers to combine their HR roles more effectively;

- Holds managers responsible for people management;

- Helps managers to access relevant information and data, conduct analyses, make decisions, and communicate with colleagues;

- Allows employees to update and make decisions about their own personal information

4) Improving HR strategic orientation:

- Helps to provide HR with the ability to create new ways of contributing to organizational effectiveness through tools such as knowledge management and social capital;

- Increases competitiveness by improving HR operations;

- Produces a greater number and variety of HR-related reports;

- Changes the focus of HR from the processing of transactions to strategic HRM;

- Makes employees part of HRIS;

- Reengineers the entire HR function of companies.
Lengnick-Hall \& Moritz, 2003; Ruel, et al., 2004; Roehling, et al., 2005; Ruta, 2005; Martin, et al., 2009; Mohapatra, 2009

Beckers \& Bsat, 2002; Kovach, et al., 2002; Sadri \& Chatterjee, 2003; Strohmeir, 2006

Dileep (2010) indicates that HRIS is a combination of HRM and information systems, as HRIS assists HR managers in performing HR functions more effectively and systematically through the use of technology. The use of a HRIS would decrease HR costs by automating information and decreasing the number of HR employees, by helping employees to control their own personal information, and by allowing managers to access relevant information and data, conducts analyses, make decisions, and communicate with others without the help of an HR professional (Ball, 2001; Awazu \& Desouza, 2003).

Through the appropriate use of HRIS, such as automating and devolving many routine HR tasks to line management, HR professionals would be able to focus on more business critical and strategic level tasks, such as leadership development and talent management (Lawler et al., 2003). HRIS also helps HR to play a more strategic role through their ability to generate real time reports on HR issues, including workforce planning and skills profiles, which can be used to support strategic decision making (Hendrickson, 2003; Lengnick-Hall et al., 2003; Lawler et al., 2004). Bourini (2011) emphasized that implementing HRIS can lead to HR professionals providing added value to the company. Proper use of HRIS can enhance the standing of HR professionals within their companies.

\subsection{Perceived Barriers to the Adoption of HRIS}

The literature on HRIS implementation suggests that many organizations have dealt with challenges when implementing new technologies, including HRIS. Beckers and Bsat (2002) state that the main obstacle in the implementation of an HRIS, is the high cost of set up and maintenance. Ngai and Wat (2006) and Batool et al. (2012) also note that the lack of funds and a trained staff are the greatest barriers. Kovach and Cathcart (1999) reach a similar conclusion, stating that a lack of financing and support from top-level management were the biggest impediments to achieving the full potential of HRIS. They also argued HRIS implementation suffered from a lack of HR knowledge amongst system designers and the lack of technology knowledge amongst HR users.

A survey conducted by the Institute of Management and Administration (2002) found that the greatest barriers to managing an HRIS include a lack of qualified HRIS staff, the lack of sufficient funding, challenges with time management, the need to work with other departments, and the lack of appropriate IT support. Brown (2002) notes that there is an inevitable transition cost of moving from traditional HR to an HRIS, including slowdowns, mistakes, and other consequences associated with changing legacy systems to integrated suites (Brown, 2002). Oleary, et al. (2002) also found that the integration of information technology could result in organizational leaders having less direct interaction with the work force, as more routines become automated. Altarawneh and Al-Shqairat (2010) identified several cultural and financial barriers to implementing HRIS.

Previous studies investigating IT adoption and implementation have shown that for more complicated technologies, such as HRIS applications, perceived obstacles are more relevant because the adoption process tends to be more complicated and costly (Hong \& Zhu, 2006). Several other organizational factors that can discourage technology adoptions were also found, such as the cost of technology, a lack of managerial and technological skills, a lack of system integration, a lack of financial resources, the lack of a reliable source of 
information for companies to gain knowledge in HRIS, and insufficient knowledge and experience in communicating information about new systems (Nilankantan \& Scamell, 1990; Swatman \& Swatman, 1991; Pfeiffer, 1992; Saunders \& Clark, 1992; Cragg \& King, 1993; Iacovou, Benbasat, \& Dexter, 1995).

Previous empirical findings further supported the argument that economic costs and lack of technical knowledge are two of the most important factors that impede IT growth in small organizations (Cragg \& King, 1993). This conclusion was consistent with a paper by Kwon and Zmud (1987), which found that successful technology implementation is more likely to occur when organizational resources (eg. time, funding, and technical skills) are positively supported during the early stages of implementation. Bussler and Davis (2001) argue that security is another factor to consider for HR and IT professionals, as with any software system. HR, by its very nature, deals with confidential data and companies must be respectful in how they manage that data. Hussain et al. (2007) mentions the importance of keeping up to date on any changes to HRIM software and prioritizing the security of HR information systems.

Another important factor is resistance to change, as employees may feel safer with the old paper system (Ostermann et al., 2009). Most organizations greatly underestimate the cultural impact of technology on their employees. HR should give the same priority to addressing these changes with employees as they do the training and implementation of software, assessing the level of employee skill and acceptance of technology and arranging training and mentoring programs within staff groups to help stressed employees. Ideally, employees should play a role in the development of the HR system (Bussler \& Davis, 2001-2002; Misra, 2006). An additional list of barriers to address include a lack of management commitment, satisfaction with the status quo, an insufficient needs analysis, a failure to include key decision-makers, intra- and interdepartmental politics, a lack of communication, and bad timing (Mohapatra, 2009).

Table 3. A summary of perceived barriers of the adoption of HRIS

\begin{tabular}{ll}
\hline Barriers & Previous Studies \\
\hline Insufficient financial support & Cragg \& King, 1993; Goodacre \& Tonks, 1995; Beckers \& Bsat, 2002; Hong \& \\
& Zhu 2006; Batool, 2012 \\
Lack of expertise in IT & Yap, et al., 1992; Chapman \& Webster, 2003; Ngai \& Wat, 2006; Batool, 2012 \\
Lack of IT vendor support & Ngai \& Wat, 2006 \\
Inadequate knowledge in implementing the system & Nilankantan \& Scamell, 1990; Benbasat \& Dexter, 1995 \\
Lack of communications & Ngai and Wat, 2006; Mohapatra, 2009 \\
Network problem & Hollenstein, 2004; Misra, 2006 \\
Technical problem & Cragg \& King, 1993; Beckers \& Bsat, 2002 \\
Lack of IT specialist & Ngai \&Wat, 2006 \\
Time consumptions & Mohapatra, 2009; Batool, et al., 2012 \\
Security/privacy fears & Ngai \& Wat, 2006 \\
Inability to prove needs & Hong \& Zhu, 2006 \\
Staff resistance to change/ culture problem & Mohapatra, 2009 \\
Inadequate technical infrastructure & Mohapatra, 2009 \\
Lack of top managers' commitment & Kovach \& Cathcart, 1999 \\
\hline
\end{tabular}

\section{Research}

This section details the research methodology, results, and analysis undertaken by the researchers.

\subsection{Research Hypotheses}

Based upon the literature review and the study objectives, the following hypotheses are proposed:

$\mathbf{H}_{\mathbf{0}}$ (1): There is no statistically significant relationship between the perceived benefits of HRIS applications and the extent of its being practiced in Jordanian shareholding companies.

$\mathbf{H}_{0}$ (2): There is no significant relationship between the perceived barriers to the practice of HRIS and the extent of its being practiced in Jordanian shareholding companies.

$\mathbf{H}_{\mathbf{0}}$ (3): There is no statistically significant relationship between the perceived benefits of HRIS applications and the extent of its being practiced in Jordanian shareholding companies due to their demographic characteristics (e.g. type of business, organization size, and level of business experience). 
$\mathbf{H}_{\mathbf{0}}$ (4): There is no statistically significant relationship between the perceived barriers to the practice of HRIS and the extent of its being practiced in Jordanian shareholding companies due to their demographic characteristics (e.g. type of business, organization size, and level of business experience).

\subsection{Research Methodology}

The purpose of this study is to determine the relationship between the perceived benefits and barriers of HRIS and the extent of its being used by business organizations. Additionally, this study aims to examine the relationship between HRIS usage among business organizations and their demographic characteristics. The data for this research was collected through a self-administrated questionnaire with 275 respondents. The target respondents were shareholding companies in Jordan.

The survey units used in this study are the individual business firms, a choice derived from the nature and the objectives of the study. The identification of the individual business organizations within the country (Jordan) was accomplished by obtaining the names of all firms, as well as their addresses, from a variety of private and public sources in order to identify the type of business sector and the number of firms in each sector. Restrictions on time and financial resources would make the inclusion of all business organization impossible; therefore, the target population is limited to the shareholding companies listed in the Amman Stock Exchange Market database. Table 4 demonstrates the domain of the study's population and number of respondents by sector. Out of 275 companies, only 236 companies responded to the questionnaire, making the response rate 85 percent of the sample size.

Table 4. Domain of the study's respondents

\begin{tabular}{cccc}
\hline Type of Companies & Number of Companies & Number of Respondents & Percentage (\%) \\
\hline Banks & 16 & 15 & 93.75 \\
Insurance & 27 & 23 & 85.00 \\
Services & 154 & 131 & 85.00 \\
Manufactures & 78 & 68 & 87.00 \\
Total & $\mathbf{2 7 5}$ & $\mathbf{2 3 6}$ & $\mathbf{8 5 . 0 0}$ \\
\hline
\end{tabular}

A total of 275 questionnaires were distributed to the respondents by mail and by hand (in response to request for information about research timeline). Initially, research assistants called the companies to arrange an appointment to distribute copies of questionnaire. After respondents answered the questions, the assistants collected the copies from them.

In this survey, some variables are factual (such as an organization's demographic, size, type of business, and experience level), whereas others are perceptual (perceived benefits and perceived barriers). All perceptual variables are measured using multi-item constructs that have been previously tested. The dependent variable - the extent of HRIS applications usage - is measured using a five-point scale: from 1 (not implemented at all) to 5 (highly implemented). The independent variables - perceived benefits and barriers - are measured using a Likert five-point scale.

\subsubsection{Data Analysis Techniques}

For the analysis, the collected data was coded into SPSS and underwent several different statistical analyses and tests. To begin, some descriptive analyses were made to describe the data. Next, the primary data was analyzed by a variety of statistics techniques including: multiple regression analysis, F. test, t. test and ANOVA. A reliability analysis was carried out for each variable: perceived benefits and perceived barriers of the use of HRIS. The results score ranged from 0.91 to 0.94 , within acceptable levels, as shown in Table 5.

Table 5. Reliability analysis variables

\begin{tabular}{ccc}
\hline Variables & Cronbach's Alpha & Number of items \\
\hline Perceived benefits & 0.94 & 13 \\
Perceived barriers & 0.91 & 13 \\
\hline
\end{tabular}




\subsubsection{Population Description}

Table 6 demonstrates the descriptive analysis for the respondent business organizations by size and business experience.

Table 6. Descriptive analysis of the study's respondents

\begin{tabular}{lcc}
\hline Characteristics & Frequency & Percentage (\%) \\
\hline Size: Number of Employees & & 11.4 \\
Less than 50 employees & 27 & 20.3 \\
Between 50 to 99 employees & 48 & 19.5 \\
Between 100 to 199 employees & 46 & 20.8 \\
Between 200 to 299 employees & 49 & 28.0 \\
Between 300 to 399 employees & 66 & \\
Business Experience & & 6.4 \\
Less than 5 years & 15 & 24.2 \\
Between 5 to 10 years & 57 & 33.9 \\
Between 11 to 15 years & 80 & 20.3 \\
Between 16 to 20 years & 48 & 15.3 \\
More than 21 years & 36 & \\
\hline
\end{tabular}

From the table above, it can be concluded that about half of responding companies (48.8\%) have more than 200 employees, 27 companies (11.4\%) have less than 50 employees, and 48 companies (20.3\%) have between 50 to 100 employees. It can also be observed that the majority of companies (69.2\%) have more than 10 years of experience, 57 companies (24.2\%) have experience between 5 to 15 years' experience, and 15 companies (6.4\%) have less than five years of experience.

\subsubsection{The Extent of HRIS Applications Usage}

In this study, the uses of HRIS for ten HRM applications were identified. These ten applications were chosen, as they were the most common applications frequently mentioned in HRIS books and HR magazines. The result is presented in table 7. This result is consistent with previous work, as the previous research on HRIS has that HRIS is usually used for administrative purposes such as employee record-keeping and payroll, instead of for strategic purposes (Ball, 2001; Kovach et al., 2002; Ngai \& Wat, 2006; Hussain et al., 2007; Delorme \& Arcand, 2010).

Table 7. HRIS applications

\begin{tabular}{lccc}
\hline HRIS Applications & Mean & Percentage & Standard Deviation \\
\hline Employee record-keeping & 4.52 & $90.4 \%$ & 0.701 \\
Recruitment/selection & 4.20 & $84.0 \%$ & 0.855 \\
Payroll service and benefits & 4.10 & $82.0 \%$ & 0.774 \\
Benefits management & 3.75 & $75.0 \%$ & 0.765 \\
Training \& Development & 4.21 & $84.2 \%$ & 0.824 \\
Performance appraisal / Reward management & 3.80 & $76.0 \%$ & 0.876 \\
Compensation management & 3.47 & $71.4 \%$ & 1.166 \\
Turnover tracking / Job analysis & 3.37 & $67.4 \%$ & 0.988 \\
Internal and external communication & 3.50 & $70.0 \%$ & 0.876 \\
Succession Planning & 3.45 & $69.0 \%$ & 0.804 \\
\hline
\end{tabular}

The results indicate that the extent of HRIS usage is considered to be moderate (i.e., 3.50\%), as the mean is more than the mean of the scale, which is 3 (i.e., Mean of the scale $=\Sigma$ Degrees of the scale $/ 5=1+2+3+4+5 / 5=3$ ). This implies that there are some variations among shareholding companies in terms of their level of implementation of HRIS applications. This is possibly because some of the management in these companies would prefer to use these applications for administrative purpose rather than for strategic purposes. 


\subsubsection{The Extent of Perceived Benefits of HRIS Applications Usage}

Table 8 demonstrates the descriptive analysis for the questions measuring the perceived benefits of HRIS applications usage. These results show that roughly $70 \%$ (3.51) of the respondents agree that the use of HRIS applications is beneficial to their company. It is apparent from the table that the majority of the questions received a positive response, as the results mean exceeded the measuring tool mean. The results also show that "Quick response time", "Accurate HR information", "Reduction in paperwork", "Reducing data re-entry", and "Tracking and controlling" are perceived as the most beneficial.

Table 8. Descriptive analysis for the questions measuring the perceived benefits of HRIS applications usage

\begin{tabular}{lcc}
\hline Benefits of HRIS Applications Usage & Mean & Standard Deviation \\
\hline - Facilitation of the recruitment process & 3.4463 & 0.97426 \\
- Streamlining HR processes & 3.6942 & 0.88358 \\
- Reducing manpower & 3.4959 & 0.86722 \\
- Reducing data re-entry & 3.9174 & 0.88116 \\
- Standardizing programs and procedures & 3.7851 & 0.84859 \\
- Cost effectiveness & 3.6612 & 0.75888 \\
- Reduction in paperwork & 3.9339 & 0.97242 \\
- Quick response time & 4.0661 & 0.89196 \\
- Accurate HR information & 4.0579 & 0.88786 \\
- Improves decision making & 3.8760 & 0.97100 \\
- Enhancing competitiveness & 3.8099 & 0.99427 \\
- Tracking and controlling & 3.9091 & 1.04881 \\
Mean & $\mathbf{3 . 5 1 1 3}$ & $\mathbf{0 . 5 7 8 1 5}$ \\
\hline
\end{tabular}

\subsubsection{The Extent of Perceived Barriers Inhibiting the Use of HRIS Applications}

Table 9 demonstrates the descriptive analysis for the questions measuring the perceived barriers inhibiting the use of HRIS applications in shareholding companies. The table shows that the greatest barriers to implementing HRIS in shareholding companies are "Lack of security of HRIS," "Inadequate technical infrastructure," "Employees feeling that technology is changing too rapidly," "Lack of commitment and involvement by all," and "Lack of expertise/knowledge in IT."

Table 9. Descriptive analysis for the questions-measuring the perceived barriers inhibiting the use of HRIS applications

\begin{tabular}{lcc}
\hline Barriers to HRIS Applications Usage & Mean & Standard Deviation \\
\hline - Inadequate technical infrastructure & 3.8777 & 1.10465 \\
- Lack of security of HRIS & 4.2355 & 1.21634 \\
- HRIS technology is not compatible with other systems we use. & 3.2033 & 1.19359 \\
- Shortage of financial resources has hindered the acquisition of new IT application in HRIS & 2.7529 & 1.24305 \\
- Poor quality of inter-communication within organization & 3.4332 & 1.24886 \\
- Lack of top management support to use IT applications such as HRIS & 3.3107 & 1.34436 \\
- The high cost of using such a system & 3.2347 & 1.26720 \\
- Employees feeling that technology is changing too rapidly & 3.8678 & 1.27764 \\
- Lack of commitment and involvement by all & 3.7355 & 1.29595 \\
- Staff resistance to change & 3.2355 & 1.30236 \\
- A lot of paper work that is difficult to computerize & 3.4164 & 1.32084 \\
- Lack of confidence in the ability of computer vendors to provide ongoing service and support & 3.1438 & 1.25518 \\
$\quad$ after implementation & & 1.33953 \\
- Lack of expertise/knowledge in IT & 3.5512 & $\mathbf{3 . 4 6 1 4}$ \\
Mean
\end{tabular}




\subsubsection{Normality Distribution Analysis}

Table 10 demonstrates the descriptive statistics for the population of the study, showing the mean, standard deviation, maximum, minimum, skewness, and kurtosis. The descriptive statistics represent the independent variables-perceived benefit and barriers-used to examine the impact on the dependent variable-the extent of HRIS applications usage. The normality of the data was assessed using the skewness and kurtosis statistics derived from the descriptive statistics, which should have a range of -1 to +1 . If the data is above range, then the distribution is normally distributed and the data must be transformed to normal distribution in order to perform the necessary statistical tests. The researcher decided to transform the data to a normal score. Table 10 shows the variables after transformation of the data into a normal score. Consequently, the assumption of normality is met.

Table 10. Normality distribution analysis

\begin{tabular}{lcc}
\hline Descriptive statistics & Benefits & Barriers \\
\hline Mean & 3.5131 & 3.4614 \\
Standard deviation & 1.23761 & 1.25971 \\
Skewness & 0.546 & -0.382 \\
Standard Error of Skewness & 0.378 & 0.316 \\
Kurtosis & -1.023 & -1.269 \\
Standard Error of Kurtosis & 0.190 & 0.158 \\
Minimum & 1 & 1 \\
Maximum & 5 & 5 \\
\hline
\end{tabular}

\subsubsection{Correlation Analysis}

Table 11 shows the Pearson Correlation Matrix among all explanatory variables. Multicollinearity exists when the correlation between two independent variables is between -0.70 and 0.70 . As shown in table 11, an examination of the correlation matrix indicates that the coefficient of correlation is less than 0.70 . Therefore, it is possible to interpret the findings since the multicollineartiy is not severe (Hair et al., 2006).

Table 11. Correlations matrix

\begin{tabular}{cc}
\hline Perceived barriers (construct) & Perceived benefits (construct) \\
\hline
\end{tabular}

**. Correlation is significant at the 0.01 level (2-tailed).

Hair, et al. (2006) recommends assessing the tolerance and variance inflation factor (VIF). Tolerance refers to the assumption of the variability in one independent variable that does not explain the other independent variable. The VIF reveals much of the same information as the tolerance factor. The common cut off threshold is a tolerance value of 0.10 , which corresponds to a VIF value above 10 . Multicollineartiy was indicated in a tolerance level of less than 0.10 or a VIF value above 10 (Hair et al., 2006). The tolerance value for each independent variable is above the ceiling tolerance value of 0.10 , consistent with the absence of a serious level of Multicollineartiy. This judgment was further supported by a VIF value for each independent variable above the threshold value of 1.0.

Table 12. Collinearity diagnostics

\begin{tabular}{lcc}
\hline Independent Variables & Tolerance & VIF \\
\hline Perceived benefits (construct) & 0.951 & 1.052 \\
Perceived barriers (construct) & 0.931 & 1.043 \\
\hline
\end{tabular}




\subsection{Testing of Hypotheses}

This section presents a statistical examination for the research hypotheses. The purpose of these tests is to decide whether to accept the null hypotheses, designated by the symbol $\mathbf{H}_{\mathbf{0}}$, or the alternative hypotheses, designated by the symbol $\mathbf{H}_{\mathrm{a}}$. The core mechanism of the hypotheses testing is to identify whether the actual sample mean is deviated from the mean of the hypothesized sampling distribution, by which a certain value that will prove that it is wrong.

Regarding the decision criteria that will be used as a base to compare this deviation with, the author has chosen the most common decision criteria, which is the significance level at less than 0.05 . It presents the critical probability in choosing between the null hypothesis and the alternative hypothesis (William, 2000).

\subsubsection{Regression}

The standard value for $\mathrm{R}^{2}$ is 1 , which means that there is a perfect linear relationship between the dependent and independent variables. On the contrary, an $\mathrm{R}^{2}$ value equal to 0 indicates that there is no linear relationship between the dependent and independent variables. In this model, the $\mathrm{R}^{2}$ value for the first stage of analysis regression model is 0.618 (refer to Table 13), which means that the contingency factors (benefits and barriers) explain about $62 \%$ of the variance in the extent of HRIS applications usage. The other $32 \%$ is due to others variables, not covered in this study.

$$
\text { Level of HRIS }=1.233+0,923 \text { benefits }+(-457) \text { barriers }+0,735
$$

Table 13. Testing the relationship between the perceived benefits and barriers and the level of implementation of HRIS: taken together

\begin{tabular}{ccccccccc}
\hline Mode & $\mathrm{R}$ & $\mathrm{R}$ Square & Adjusted R Square & Std. Error of the Estimate & df & F & Sig. \\
\hline 1 & $.647^{\mathrm{a}}$ & .418 & .413 & .96476 & 2 & 83.828 & $.000^{\mathrm{b}}$ \\
\hline
\end{tabular}

a. Dependent Variable: HRIS;

b. Predictors: (Constant), Barriers, benefits.

Table 14. Coefficient of the multiple regression model

\begin{tabular}{|c|c|c|c|c|c|}
\hline \multirow{2}{*}{ Model } & \multicolumn{2}{|c|}{ Un-standardized Coefficients } & \multirow{2}{*}{$\begin{array}{c}\text { Standardized Coefficients } \\
\text { Beta }\end{array}$} & \multirow{2}{*}{$\mathbf{T}$} & \multirow{2}{*}{ Sig. } \\
\hline & $\mathbf{B}$ & Std. Error & & & \\
\hline - Constant & -1.233 & .735 & & & \\
\hline - Perceived Benefits & .923 & .150 & .435 & 6.147 & .000 \\
\hline - Perceived Barriers & -.457 & .089 & -.339 & -5.163 & .000 \\
\hline
\end{tabular}

a. Dependent Variable: Level of Implementation of HRIS.

Table 14 (above) lists the beta coefficient for both perceived benefits and barriers factors. It gives measure of the contribution of each factor to the model. A greater value indicates that a unit change in this predictor factor has a greater effect on the dependent variable - the level of implementation of HRIS applications. The table indicates that the Beta coefficients of perceived benefits show that perceived benefits are a more important determinant associated with the level of the implementation of HRIS applications in shareholding companies than perceived barriers are.

\subsubsection{Alternative Hypotheses}

The results in Table 13 show a significant relationship between perceived benefits and the level of HRIS usage at $(\mathrm{Sig}=0.000)$. Additionally, the result shows that for each unit increase in the independent variable, there is an expected increase of 0.435 in the dependent variable. The direction of this relationship is positive. An examination of the $\mathrm{T}$ value $(\mathrm{t}=6.147, \mathrm{p}<0.000)$ indicates that the perceived benefits contribute to increase the use of HRIS applications. Therefore, the null hypothesis $\mathbf{H}_{\mathbf{0}}(\mathbf{1})$ is rejected and the alternate hypothesis $\mathbf{H}_{\mathbf{a}}(\mathbf{1})$ is accepted.

$\mathbf{H}_{\mathbf{a}}$ (1): There is a statistically significant relationship between the perceived benefits of HRIS applications 
and the extent of its being practiced in Jordanian shareholding companies.

The results in Table 14 show a significant relationship between perceived barriers and the level of HRIS usage at $(\mathrm{Sig}=0.000)$. Additionally, the result indicates that for each unit increase in the independent variable, there is an expected decrease of -0.339 in the dependent variable. The direction of this relationship is negative. An examination of the $\mathrm{T}$ value $(\mathrm{t}=-5.163, \mathrm{p}>0.000)$ indicates that the perceived barriers contribute to decrease the use of HRIS applications. Therefore, the null hypothesis $\mathbf{H}_{\mathbf{0}}(\mathbf{2})$ is rejected and the alternate hypothesis $\mathbf{H}_{\mathbf{a}}(\mathbf{2})$ is accepted.

$\mathbf{H}_{\mathbf{a}}$ (2): There is a significant relationship between the perceived barriers to the practice of HRIS and the extent of its being practiced in Jordanian shareholding companies.

\subsubsection{ANOVA Analysis}

A one-way ANOVA test is used to determine the variations of the perceptions of HRIS benefits and barriers and the extent of its being practiced in Jordanian shareholding companies due to their demographic characteristics.

$\mathbf{H}_{\mathbf{0}}(\mathbf{3})$ : There is no statistically significant relationship between the perceived benefits of HRIS applications and the extent of its being practiced in Jordanian shareholding companies due to their demographic characteristics (e.g. type of business, organization size, and level of business experience).

The results of the one-way ANOVA test and F. test for the hypothesis $\mathbf{H}_{\mathbf{0}} \mathbf{( 3 )}$, as presented in Table 15, show significant variations of the perceived benefits of HRIS and the extent of its being used by organizations according to their business experience and number of employees, but not by the type of business that they belong to. Therefore, the null hypothesis is only accepted for the type of business. This result indicates the type of business has no significant influence upon the variations of the perception of benefits of HRIS and the extent of its being used.

Table 15. Results of one-way ANOVA analysis for HRIS benefits

\begin{tabular}{|c|c|c|c|c|c|c|}
\hline & Type of Business & & Sum of Squares & Df & Mean Square & $\mathbf{F}$ \\
\hline \multirow[t]{3}{*}{ Benefits } & Between Groups & 1.488 & 4 & 0.372 & 1.162 & 0.330 \\
\hline & Within Groups & 50.591 & 231 & 0.320 & & \\
\hline & Total & 52.080 & 235 & & & \\
\hline & Business Experience & & Sum of Squares & Df & Mean Square & $\mathbf{F}$ \\
\hline \multirow[t]{3}{*}{ Benefits } & Between Groups & 9.782 & 4 & 2.445 & 9.135 & 0.000 \\
\hline & Within Groups & 42.298 & 231 & 0.268 & & \\
\hline & Total & 52.080 & 235 & & & \\
\hline & Number of Employees & & Sum of Squares & Df & Mean Square & $\mathbf{F}$ \\
\hline \multirow[t]{3}{*}{ Benefits } & Between Groups & 4.563 & 4 & 1.141 & 3.794 & 0.006 \\
\hline & Within Groups & 47.516 & 231 & 0.301 & & \\
\hline & Total & 52.080 & 235 & & & \\
\hline
\end{tabular}

H0 (4): There is no statistically significant relationship between the perceived barriers to the practice of HRIS and the extent of its being practiced in Jordanian shareholding companies due to their demographic characteristics (e.g. type of business, organization size, and level of business experience)

The results of the one-way ANOVA test and F. test for the hypothesis $\mathbf{H}_{\mathbf{0}}(\mathbf{4})$, as presented in Table 16, show significant variations of the perceived barriers of HRIS and the extent of its being used by organizations according to their business experience, number of employees, and the type of business that they belong. No statistically meaningful difference was found between these variables. Therefore, the null hypothesis $\mathbf{H}_{\mathbf{0}}(\mathbf{4})$ is accepted for all variables included in the analysis. This result indicates that neither the type of business nor business experience nor the number of employees of the investigated organizations has any significant effect upon the variations of the perceived barriers of HRIS and the extent of its being used. 
Table 16. Results of one-way ANOVA analysis for HRIS barriers

\begin{tabular}{|c|c|c|c|c|c|c|}
\hline & Type of Business & & Sum of Squares & Df & Mean Square & $\mathbf{F}$ \\
\hline \multirow[t]{3}{*}{ Barriers } & Between Groups & 0.381 & 4 & 0.095 & \multirow[t]{3}{*}{0.435} & \multirow[t]{3}{*}{0.783} \\
\hline & Within Groups & 50.549 & 231 & 0.219 & & \\
\hline & Total & 50.930 & 235 & & & \\
\hline & Business Experience & & Sum of Squares & Df & Mean Square & $\mathbf{F}$ \\
\hline \multirow[t]{4}{*}{ Barriers } & Between Groups & 0.561 & 4 & 0.140 & \multirow[t]{3}{*}{0.644} & \multirow[t]{3}{*}{0.632} \\
\hline & Within Groups & 50.368 & 231 & 0.218 & & \\
\hline & Total & 50.930 & 235 & & & \\
\hline & Number of Employees & & Sum of Squares & Df & Mean Square & $\mathbf{F}$ \\
\hline \multirow[t]{3}{*}{ Barriers } & Between Groups & 0.551 & 4 & 0.140 & \multirow[t]{3}{*}{0.614} & \multirow[t]{3}{*}{0.612} \\
\hline & Within Groups & 50.364 & 231 & 0.218 & & \\
\hline & Total & 50.931 & 235 & & & \\
\hline
\end{tabular}

\section{Conclusion}

HRIS is an integrated system comprised of the databases, computer applications, hardware, and software necessary to collect, record, store, manage, deliver, present, and manipulate data for a company's human resources function (Broderick \& Boudreau, 1992). Results indicate that the most frequently used applications of HRIS by business organizations in Jordan are "Employee Records," followed by "Pay Roll" and "Recruitment/Selection." Usage of sophisticated HRIS applications, such as "Succession Planning," "Performance Appraisal," "Compensation Management," and "Training and development," was also found in Jordanian business organizations. This study concludes that the scope of HRIS applications usage has broadened in Jordan. Although operating HRIS applications, such as "Employee Records" and "Pay Roll," remain the most popular, there has been an increase in the use of HRIS for sophisticated activities and decision-making. Previous studies support these findings (Cedar Crestone, 2006; Saharan \& Jafri, 2012).

Results also showed that "Quick response time," "Accurate HR information," "Reduction in paperwork," "Reducing data re-entry," and "Tracking and controlling" are perceived as the most beneficial HRIS applications from the respondents' perspective. Furthermore, results indicated that the greatest barriers inhibiting the use of HRIS applications are "Lack of security of HRIS," "Inadequate technical infrastructure," "Employees feeling that technology is changing too rapidly," "Lack of commitment and involvement by all," and "Lack of expertise/knowledge in IT."

A regression analysis indicated that there was a significant, moderate relationship between the perceived benefit and barriers of HRIS and the extent of its usage. This result is supported by several previous studies, including Fillis et al. (2003), Cedar Crestone (2005), Panayotopoulou (2005), Hooi (2006), Ngai and Wat (2006), Panayotopoulou et al. (2006), Kovach et al. (2007), Teo et al. (2007), and Junaid et al. (2010). Furthermore, ANOVA analysis results indicated that variations in the relationship between the perceived benefits of HRIS and the extent of its usage could be due to a business' size and experience level. However, the type of business was not found to be an important factor. Finally, results indicated that neither the type of business, level of business experience, nor the number of employees in an organization has any significant impact upon the variations of the perceived barriers of HRIS and the extent of its usage.

This study is the first investigation of the state of HRIS use in Jordan, and hence can be immensely valuable to managers within the country. The study both offers encouraging statistics about the potential for HRIS use in Jordan in types of organizations, as well as provides specific guidance as to what aspects of HRIS companies may benefit from emphasizing. Specifically, the aspects of HRIS that are seen as most beneficial are not currently those that are most widely utilized. The new information on important barriers to adoption can also guide managers in how to potentially overcome these concerns. The study also represents one of the first studies of HRIS adoption in the developing world, hence provides valuable data about the viability of HRIS outside of developed countries. This also highlights a need for more research, as only a limited amount can be extrapolated from this case study to the developing world at large. 


\section{References}

Alleyne, C. (2002). Impact of the use of HR Internet applications on managers' satisfaction with the HR function. $\mathrm{PhD}$ Thesis, Cranfield University, School of Management. Retrieved from https://dspace.lib.cranfield.ac.uk/handle/1826/4047?mode=simple

Altarawneh, I., \& Al-Shqairat, Z. (2010). Human Resource Information Systems in Jordanian Universities. International Journal of Business and Management, 5(10), 113.

Anderson, D., Burnham, K., \& Thompson, W. (2000). Null hypothesis testing: problems, prevalence, and an alternative. The Journal of Wildlife Management, 64(4), 912-923. http://dx.doi.org/10.2307/3803199

Awazu, Y., \& Desouza, K. (2004). Open knowledge management: Lessons from the open source revolution. Journal of the American Society for Information Science and Technology, 55(11), 1016-1019. http://dx.doi.org/10.1002/asi.20050

Ball, K. (2001). The use of human resource information systems: a survey. Personnel Review, 30(6), 677-693. http://dx.doi.org/10.1108/eum0000000005979

Batool, S., Sajid, M., \& Raza, S. (2012). Benefits and Barriers of Human Resource Information System In Accounts Office \& Azad Jammu \& Kashmir Community Development Program. International Journal of Humanities and Social Sciences, 2(3), 211-217.

Beckers, A., \& Bsat, M. (2002). A DSS classification model for research in human resource information systems. $\begin{array}{llll}\text { Information } & \text { Systems } & \text { Management, } & 19(3),\end{array}$ http://dx.doi.org/10.1201/1078/43201.19.3.20020601/37169.6

Bhavsar, A. (2011). A Conceptual Paper on Human Resource Information System (HRIS). Golden Resource Thoughts, 1(5), 1.

Boateng, A. (2007). The role of human resource information systems (HRIS) in strategic human resource management (SHRM). Master of Science Theses, Accounting Swedish School of Economics and Business Administration.

Bourini, F., \& Bourini, I. (2011). Investigating the Relationship between Human Resource Information System and Strategic Capability among Employees: Jordan Case Study. Journal of Advanced Social Research, 1(1), 63-75.

Brancheau, J., \& Wetherbe, J. (1990). The adoption of spreadsheet software: testing innovation diffusion theory in the context of end-user computing. Information Systems Research, 1(2), 115-143. http://dx.doi.org/10.1287/isre.1.2.115

Broderick, R., \& Boudreau, J. (1992). Human resource management, information technology, and the competitive edge. CAHRS Working Paper \#91-19. http://dx.doi.org/10.5465/ame.1992.4274391

Brown, D. (2002). E-HR - victim of unrealistic expectations. Canadian HR Reporter, 15(5), 1-6.

Bussler, L., \& Davis, E. (2001). Information Systems: The Quiet Revolution in Human Resource Management. The Journal of Computer Information Systems, 42(2), 17-20.

Byars, L., \& Rue, L. (2004). Human Reserved Supply Management (7th ed.). New York: McGraw-Hill Companies.

Cedar Crestone. (2005). The Cedar Crestone 2005 Workforce Technologies And Service Delivery Approaches Survey (8th ed.).

Chapman, D. S., \& Webster, J. (2003). The use of technologies in the recruiting, screening, and selection processes for job candidates. International Journal of Selection and Assessment, 11(2), 113-120. http://dx.doi.org/10.1111/1468-2389.00234

Clark, T., Grant, D., \& Heijltjes, M. (1999). Researching comparative and international human resource management: key challenges and contributions. International Studies of Management \& Organization, 29(4), 6-23.

Cragg, P., \& King, M. (1993). Small-firm computing: motivators and inhibitors. MIS Quarterly, 17(1), 47-60. http://dx.doi.org/10.2307/249509

Delorme, M., \& Arcand, M. (2010). HRIS implementation and deployment: a conceptual framework of the new roles, responsibilities and competences for HR professionals. International Journal of Business Information Systems, 5(2), 148-161. http://dx.doi.org/10.1504/ijbis.2010.030626 
DeSanctis, G. (1986). Human resource information systems: a current assessment. MIS Quarterly, 10(1), 15-27. http://dx.doi.org/10.2307/248875

Dileep, A. (2010). Enterprise resource planning: the emerging organizational value systems. Industrial Management \& Data Systems, 100(3), 114-118.

Ensher, E. A., Nielson, T. R., \& Grant-Vallone, E. (2002). Tales from the Hiring Line: Effects of the Internet and technology on HR processes. Organizational Dynamics, 31(3), 224-244. http://dx.doi.org/10.1016/s0090-2616(02)00111-0

Frolick, M. N. (1994). Management support systems and their evolution from executive information systems. Information Strategy, 10(3), 31-38.

Haines, V. Y., \& Petit, A. (1997). Conditions for successful human resource information systems. Human Resource Management, 36(2), 261-275. http://dx.doi.org/10.1002/(sici)1099-050x(199722)36:2<261::aid-hrm7>3.3.co;2-x

Hair, Jr., \& J. F., et al. (2006). Multivariate Data Analysis (6th ed.). Upper Saddle River: Pearson Prentice Hall.

Hendrickson, A. R. (2003). Human resource information systems: Backbone technology of contemporary human resources. Journal of Labor Research, 24(3), 382-394. http://dx.doi.org/10.1007/s12122-003-1002-5

Hong, W., \& Zhu, K. (2006). Migrating to internet-based e-commerce: factors affecting e-commerce adoption and migration at the firm level. Information \& Management, 43(2), 204-221. http://dx.doi.org/10.1016/j.im.2005.06.003

Hooi, L. W. (2006). Implementing e-HRM: the readiness of small and medium sized manufacturing companies in Malaysia. Asia Pacific Business Review, 12(4), 465-485. http://dx.doi.org/10.1080/13602380600570874

Hussain, Z., Wallace, J., \& Cornelius, N. E. (2007). The use and impact of human resource information systems on human resource management professionals. Information \& Management, 44(1), 74-89. http://dx.doi.org/10.1016/j.im.2006.10.006

Iacovou, C., Benbasat, I., \& Dexter, A. (1995). Electronic data interchange and small organizations: Adoption and impact of technology. MIS Quarterly, 19(4), 465-485. http://dx.doi.org/10.2307/249629

Junaid, Z., Muhammad, S., \& Norazuwa, M. (2010). An Analysis of E-Human Resource Management Practices: A Case Study of State Bank of Pakistan. European Journal of Social Sciences, 15(1), 18-26.

Kettley, P., \& Reilly, P. (2003). E-HR: An Introduction. Institute for Employment Studies (United Kingdom) [Report 396]. Retrieved from http://www.employment-studies.co.uk/news/summary.php?id=398

Kovach, K. A., \& Cathcart, C. E. (1999). Human resource information systems (HRIS): Providing business with rapid data access, information exchange and strategic advantage. Public Personnel Management, 28(2), 275 282.

Kovach, K. A., Hughes, A. A., Fagan, P., \& Maggitti, P. G. (2002). Administrative and strategic advantages of HRIS. Employment Relations Today, 29(2), 43-48. http://dx.doi.org/10.1002/ert.10039

Krishna, C., \& Bhaskar, S. V. (2011). Assessment of support and benefits of HRIS in medium-scale textile industries. International Journal of Research in Economics \& Social Sciences, 1(2), 48-57.

Kwon, T. H., \& Zmud, R. W. (1987). Unifying the fragmented models of information systems implementation. In Critical issues in information systems research (pp. 227-251). New York: John Wiley \& Sons, Inc.

Lado, A., \& Wilson, M. (1994). Human Resource Systems and Sustained Competitive Advantage: A Competency-Based Perspective. The Academy Of Management Review, 19(4), 699-727.

Lau, G., \& Hooper, V. (2008). Adoption of e-HRM in large New Zealand organizations. Encyclopedia of Human Resource Information Systems, 31-41.

Lawler, E. E., \& Mohrman, S. A. (2003). HR as a strategic partner: what does it take to make it happen? Human Resource Planning, 26(3), 15-29.

Lawler, E. E., Levenson, A., \& Boudreau, J. W. (2004). HR Metrics and Analytics: Uses and Impacts. Human Resource Planning Journal, 27(4), 27-35.

Lederer, A. L. (1984). Planning and developing a human resource information system. The logic of a step-by-step approach. The Personnel Administrator, 29(8), 27-39.

Lengnick-Hall, M. L., \& Moritz, S. (2003). The impact of e-HR on the human resource management function. 
Journal of Labor Research, 24(3), 365-379. http://dx.doi.org/10.1007/s12122-003-1001-6

Lepak, D. P., Taylor, S. M., Tekleab, A. G., Marrone, J. A., \& Cohen, D. J. (2007). An examination of the use of high - investment human resource systems for core and support employees. Human resource management, 46(2), 223-246. http://dx.doi.org/10.1002/hrm.20158

Lin, C. (1997a). Human resource information systems: Implementation in Taiwan. Research and Practice in Human Resource Management, 5(1), 57-72.

Lin, C. (1997b). Human Resource Management in Taiwan: A Future Perspective. The International Journal of Human Resource Management, 8(1), 29-43. http://dx.doi.org/10.1080/09585199700000039

Martin, G. et al. (2009). Web 2.0 and Human Resource Management: 'Groundswell' or Hype? London: CIPD.

Mentzas, G. (1994). A functional taxonomy of computer-based information systems. International Journal of Information Management, 14(6), 397-410. http://dx.doi.org/10.1016/0268-4012(94)90015-9

Miltiadis, D., \& Pouloudi, A. (2003). Project management as a knowledge management prime: the learning infrastructure in knowledge-intensive organizations: projects as knowledge transformations and beyond. The Learning Organization Journal, 10(4), 237-250. http://dx.doi.org/10.1108/09696470310476007

Misra, H. (2006). Role of Human Resource in Information Technology Alignment in Organizations: A Metric Based Strategic Assessment Framework. Journal of Information Technology Management, 17(3), 139.

Mohapatra, S. (2009). Framework for HRIS implementation in non-IT sector. Journal of Convergence Information Technology, 4(4).

Ngai, E., \& Wat, F. (2004). Dominance approach to risk analysis of computer systems. Decision Support Systems, $37(4), 485-500$.

Ngai, E., \& Wat, F. (2006). Human resource information systems: a review and empirical analysis. Personnel Review, 35(3), 297-314. http://dx.doi.org/10.1108/00483480610656702

Nilakanta, S., \& Scamell, R. W. (1990). The effect of information sources and communication channels on the diffusion of innovation in a data base development environment. Management Science, 36(1), 24-40. http://dx.doi.org/10.1287/mnsc.36.1.24

O'Leary, B. S., et al. (2002). Selecting the best and brightest: Leveraging human capital. Human Resource Management, 41(3), 325-340. http://dx.doi.org/10.1002/hrm.10044

Ostermann, H., Staudinger, B., \& Staudinger, R. (2009). Benchmarking Human Resource Information Systems. In Encyclopaedia of Human Resources Information Systems: Challenges in e-HRM (pp. 92-101).

Overman, S. (1992). Reaching for the 21st Century. HR Magazine, 37(4), 61-61.

Panayotopoulou, L., Vakola, M., \& Galanaki, E. (2007). E-HR adoption and the role of HRM: evidence from Greece. Personnel Review, 36(2), 277-294. http://dx.doi.org/10.1108/00483480710726145

Papalexandris, N., \& Panayotopoulou, L. (2005). Exploring the partnership between line managers and HRM in Greece. Journal of European Industrial Training, 29(4), 281-291. http://dx.doi.org/10.1108/03090590510597133

Pfeiffer, H. K. C. (1992). The diffusion of electronic data interchange. New York: Springer-Verlag, Inc. $\mathrm{http}: / / \mathrm{dx}$.doi.org/10.1007/978-3-642-51559-0

Powell, T. C., \& Dent-Micallef, A. (1997). Information technology as competitive advantage: the role of human, business, and technology resources. Strategic Management Journal, 18(5), 375-405. http://dx.doi.org/10.1002/(SICI)1097-0266(199705)18:5<375::AID-SMJ876>3.0.CO;2-7

Roehling, M. V., et al. (2005). The future of HR management: research needs and directions. Human Resource Management, 44(2), 207-216. http://dx.doi.org/10.1002/hrm.20066

Rogers, E. (1995). Diffusion of Innovations (4th ed.). New York: The Free Press.

Ruël, H., Bondarouk, T., \& Looise, J. K. (2004). E-HRM: innovation or irritation: an explorative empirical study in five large companies on web-based HRM. Management Revue, 15(3), 364-380.

Ruta, C. D. (2005). The application of change management theory to HR portal implementation in subsidiaries of multinational corporations. Human Resource Management, 44(1), 35-53. http://dx.doi.org/10.1002/hrm.20039

Sadri, J., \& Chatterjee, V. (2003). Building organizational character through HRIS. International Journal of 
Human Resources Development and Management, $\quad 3(1), \quad 84-98$. http://dx.doi.org/10.1504/IJHRDM.2003.001048

Saharan, T., \& Jafri, S. (2012). Valuation of HRIS Status an Insight of Indian Companies' Perspectives. In Kundu, S. C., Punia, B. K., Narwal, K. P., \& Singh, D. (Eds.), Business Management: Key Research Issues (pp. 113 27). New Delhi: Excel Books.

Saunders, C. S., \& Clark, S. (1992). EDI adoption and implementation: A focus on inter-organizational linkages. Information Resources Management Journal, 5(1), 9-20.

Snell, S. A., Stueber, D., \& Lepak, D. P. (2002). Virtual HR Departments. In Heneman, R., \& Greenberger, D. (Eds.), Human resource management in virtual organizations (p. 81). USA: Information Age Publishing.

Soft World Report. (1996). Human Resource Management Software. Conspectus, PMP (UK) Ltd.

Strohmeier, S. (2007). Research in e-HRM: Review and implications. Human Resource Management Review, 17(1), 19-37. http://dx.doi.org/10.1016/j.hrmr.2006.11.002

Swatman, P. M. C., \& Swatman, P. A. (1991). Electronic data interchange: organisational opportunity, not technical problem. Databases in the 1990's, 2, 354-374.

Tannenbaum, S. (1990). Human resource information systems: user group implications. Journal of Systems Management, 41(1), 27-32.

Teo, T. S. H., Lim, G. S., \& Fedric, S. A. (2007). The adoption and diffusion of human resources information systems in Singapore. Asia Pacific Journal of Human Resources, 45(1), $44-62$. http://dx.doi.org/10.1177/1038411107075402

Vitale, M. R., \& Johnson, H. (1988). Creating competitive advantage with inter-organizational information systems. MIS Quarterly, 12(2), 152-165.

Wagner, B., Fillis, I., \& Johansson, U. (2003). E-business and e-supply strategy in small and medium sized businesses (SMEs). Supply Chain Management: An International Journal, 8(4), $343-354$. http://dx.doi.org/10.1108/13598540310490107

Wright, P. M., \& Dyer, L. (2000). People in the e-business: new challenges, new solutions. CAHRS Working Paper (\#00-11). Retrieved from http://digitalcommons.ilr.cornell.edu/cahrswp/89

Yeung, A., \& Brockbank, W. (1995). Reengineering HR through information technology. Human Resource Planning, 18(2), 24-37.

Zampetti, R., \& Adamson, L. (2001). Web-based employee self-service: a win-win proposition for organizations and employees. In Walker, A. (Ed.), Web-based human Resources (pp. 15-23). New York: McGraw-Hill.

\section{Copyrights}

Copyright for this article is retained by the author(s), with first publication rights granted to the journal.

This is an open-access article distributed under the terms and conditions of the Creative Commons Attribution license (http://creativecommons.org/licenses/by/3.0/). 